Teologia i Moralność, Volumen 15(2020), numer 1(27)

doi: 10.14746/tim.2020.27.1.05

ORCID: 0000-0003-4271-8478

\author{
WOJCIECH KUĆKO \\ Uniwersytet Kardynała Stefana Wyszyńskiego w Warszawie \\ Wydział Studiów nad Rodziną
}

\title{
Dylematy sakramentu pokuty i pojednania w kontekście nadużyć seksualnych wobec nieletnich w świetle nauczania papieża Franciszka
}

Historyczna decyzja Franciszka z 2019 roku o zniesieniu sekretu papieskiego w procesach dotyczących nadużyć seksualnych z użyciem przemocy oraz nadużyć seksualnych wobec nieletnich i osób bezradnych (por. Arrieta 2019, s. 4-5), która otworzyła archiwa kościelne dla dochodzeń prowadzonych przez władze świeckie, była ważnym krokiem w kierunku wymierzania sprawiedliwości i dalszego leczenia ran wspólnoty Kościoła. Obok przepisów prawa kościelnego i cywilnego, niemniej istotna jest sfera forum internum, a szczególnie sakramentu pokuty, będącego nierzadko jedyną rzeczywistością, w której sprawca nadużyć seksualnych ma do czynienia z osądem swojego działania. Praktyka sakramentu pokuty i pojednania oraz przedstawiane dane, dotyczące nadużyć seksualnych wobec małoletnich, pozwalają domniemywać, że w kontekście spowiedzi częściej mamy do czynienia z wyznawaniem grzechu przez ofiary czynów pedofilskich niż przez tych, którzy byli ich autorami (por. Beretta 2019).

Celem niniejszego artykułu jest pokazanie złożoności dylematów sakramentu pokuty i pojednania w kontekście nadużyć seksualnych wobec nieletnich. W tekście zamiennie będą stosowane terminy pedofilia oraz nadużycia seksualne wobec nieletnich, które zdarzają się w wielu grupach dorosłych, zajmujących się edukacją nieletnich, sportem, rozrywką etc. (por. Kobyliński 2018, s. 55-56). Dramat pedofilii w bardzo wielu krajach świata doprowadził do zgubnych skutków w religijności, które Andrzej Kobyliński określa jako sprzężenie zwrotne: „[...] z jednej strony, rewolucja seksualna i gwałtowny proces sekularyzacji stworzyły podatny grunt do rozwoju pedofilii, z drugiej - 
dramat seksualnego wykorzystania dzieci przyczynił się do jeszcze głębszego rozpadu tradycyjnej religijności" (Kobyliński 2017, s. 231). Doprowadziło to także do pewnego kryzysu przeżywania sakramentu pokuty, przejawiającego się poprzez zarzucanie spowiedzi indywidualnej w wielu dawniej tradycyjnie katolickich krajach albo kwestionowanie potrzeby tego sakramentu. Opisanie zjawiska pedofilii i jej oceny moralnej w historii teologii katolickiej i prawa kanonicznego pozwoli na ukazanie kwestii odpowiedzialności różnych osób, włączonych w sakrament pokuty, w kontekście wyznawania tego grzechu: od kapłana spowiednika, przez penitentów, którymi mogą być zarówno ofiary tych nadużyć, jak i sprawcy pedofilii oraz ich przełożeni, aż po pytanie o odpowiedzialność całej wspólnoty wierzących za ograniczanie negatywnych skutków społecznych tych nadużyć.

\section{Holokaust pedofilii}

W 2002 roku ukazała się książka pt. La pedofilia. I mille volti di un olocausto silenzioso [Pedofilia. Tysiac twarzy milczacego holokaustu] Fortunata Di Noto, włoskiego kapłana walczącego z plagą pedofili i działającego na rzecz ochrony dzieci (por. Kobyliński 2003). W 1989 roku utworzył on Associazione METER, natomiast w 1996 roku założył stowarzyszenie Telefono Arcobaleno [Tęczowy Telefon], które są przestrzenią opracowywania i realizowania strategii ochrony dzieci i młodzieży przed złem pedofilii. Te w owym czasie nowatorskie w skali świata działania pokazały, jak bardzo ważne jest podjęcie przez Kościół katolicki działań, zmierzających do jasnego przeciwstawienia się pedofilii, i walka z tym przestępstwem, także w szeregach ludzi Kościoła. Od 1989 roku, gdy Zgromadzenie Ogólne ONZ przyjęło Międzynarodową Konwencję Praw Dziecka, zaczęto mówić głośno o ochronie dzieci przed każdą formą ich wykorzystywania seksualnego.

Zasięg zjawiska pedofilii na początku XXI wieku każe niewątpliwie uznać, że jest ono swoistą formą holokaustu, cichej zagłady wielu tysięcy dzieci. Podczas przemówienia na zakończenie zorganizowanego po raz pierwszy $\mathrm{w}$ historii w tak szerokim wydaniu watykańskiego spotkania (ang. summit) na temat pedofilii (21-24 lutego 2019) Franciszek stwierdził: „Przywodzi mi to na myśl także okrutną praktykę religijną, rozpowszechnioną w przeszłości w niektórych kulturach, jaką było składanie ludzi - często dzieci - na ofiarę w obrzędach pogańskich. Jednakże do dzisiaj dostępne liczby dotyczące nadużyć seksualnych wobec nieletnich, dostarczane przez różne organizacje i instytucje państwowe i międzynarodowe (WHO, UNICEF, INTERPOL, EUROPOL i inne) nie ukazują prawdziwych rozmiarów zjawiska, często szacowanego zbyt nisko głównie dlatego, że wiele przypadków wykorzystywania seksu- 
alnego nieletnich nie jest zgłaszanych, a dotyczy to w szczególności bardzo licznych nadużyć popełnianych w środowisku rodzinnym" (Franciszek 2019b, s. 22). Papież słusznie zauważył, że zgłaszanych jest jedynie $2 \%$ przypadków, natomiast szacunki mówią o 15-20\% osób w społeczeństwie, będących ofiarami pedofilii.

Rzeczywistość pedofilii, choć nie nowa w historii ludzkości, staje się na początku trzeciego tysiąclecia jednym z palących problemów wspólnoty Kościoła. Prowadzone akcje prewencyjne, działania uświadamiające i uwrażliwiające, a także wiele dokumentów Kościoła katolickiego są ważne na forum externum. Nie mniej istotne wydaje się jednak podjęcie tematu grzechu pedofilii na forum internum. Sakrament pokuty i pojednania jest jedną z przestrzeni rozstrzygania dylematów sumienia zarówno sprawców, jak i ofiar pedofilii. Ze względu na sigillum sacramentale trudno rozstrzygnąć, jaki procent jednych i drugich korzysta $\mathrm{z}$ łaski sakramentalnej, niemniej jednak ta rzeczywistość jest jedną $z$ trudniejszych $w$ rozstrzyganiu moralnym $w$ konfesjonale.

Jak bardzo ten temat uważany jest za istotny, wynika choćby z pobieżnego przeglądu działalności Stolicy Apostolskiej w ostatnich latach. Z okazji wspomnianego watykańskiego szczytu, poświęconego ochronie nieletnich, w 2019 roku została opracowana specjalna wielojęzyczna strona internetowa https:// www.pbc2019.org/it/home, zatytułowana: The Protections of Minors in the Church. Responsability, Accountability, Trasparency, zawierająca m.in. chronologię odpowiedzi Kościoła na poziomie lokalnym i powszechnym od 1984 roku aż do obecnych czasów ${ }^{1}$. Działania papieży: św. Jana Pawła II, Benedykta XVI i Franciszka doprowadziły również do powstania Papieskiej Komisji ds. Ochrony Nieletnich (22 marca 2014) (por. Franciszek 2015a, Secretaria Status 2015).

\section{Trudności terminologiczne}

Termin paedophilia erotica do dyskursu medycznego wprowadził w 1886 roku austriacko-niemiecki seksuolog Richard von Krafft-Ebing (1840-1902) w dziele Psychopathia Sexualis. Jak wskazują badacze, współcześnie funkcjonuje wiele różnych definicji pedofilii, ponadto ,jako kategoria diagnostyczna i zaburzenie seksualne mylona jest ona ze społeczną etykietą osoby molestującej seksualnie dzieci” (Marcinek i Kapała 2012, s. 76-77). Pedofilię nale-

\footnotetext{
${ }^{1}$ Obrady watykańskie rozpoczęły się 21 lutego 2020 r., kiedy w kalendarzu liturgicznym wspominany jest św. Piotr Damiani (1007-1072), kardynała i biskupa Ostii, doktora Kościoła, autora Liber Gomorrhianus (1049), słynnego traktatu na temat grzechów przeciwko naturze, także wśród duchowieństwa.
} 
ży zatem odróżnić od wykorzystywania seksualnego dzieci (children sexual abuse, CSA), związanego również z działalnością organizacji przestępczych o charakterze międzynarodowym, będących przejawem struktur zła w świecie.

Pedofilia (gr. paidion - 'dziecko', filia - 'miłość') byłaby zatem utrwaloną lub dominującą preferencją seksualną do aktywności seksualnej zwykle z dzieckiem lub dziećmi w okresie przedpokwitaniowym lub we wczesnym okresie dojrzewania (por. Marcinek i Kapała 2012, s. 77). Psychiatrzy wskazują tutaj, że kryterium wieku dziecka dotyczy jego wieku rozwojowego, a nie chronologicznego, co jeszcze bardziej komplikuje kwestie etycznej oceny tego zjawiska. W przypadku nadużyć w stosunku do nastolatków w pierwszym okresie dojrzewania mówi się o efebofilii. Pedofilia jest dewiacją seksualną z grupy parafilii, mającą charakter patologicznego odchylenia seksualnego. Ważne dla oceny moralnej są wskazywane przez psychiatrów cechy takiego odchylenia - może ono bowiem charakteryzować się przymusowością działania, nałogowością, dużą częstotliwością, różnego rodzaju fantazjami i stopniami dewiacji, od łagodnej, przez umiarkowaną, aż do ciężkiej (por. Prusak 2009, s. 469-470). Należy dodać, że w kolejnych wydaniach Diagnostic and statistic manual of mental disorders, klasyfikacji zaburzeń psychicznych, opracowywanej przez Amerykańskie Towarzystwo Psychiatryczne, pedofilia była różnie definiowana $\mathrm{w}$ grupie parafilii, a coraz liczniejsze są grupy osób, które podnoszą kwestię „normalizacji” pedofilii, zarówno na płaszczyźnie prawnej, społecznej, jak i moralnej (por. Faggioni 2017, s. 313-319).

\section{Ocena moralna czynów pedofilskich w historii teologii}

Zanim zostanie ukazane obecne postrzeganie grzechu pedofilii, warto prześledzić historię interpretacji tego zjawiska na przestrzeni wieków, w myśli teologicznej i kanonicznej Kościoła katolickiego.

Różne ujęcia seksualności związane są z wieloma kulturami i tradycjami w świecie. Analiza kulturalna i społeczna nie powinna jednak prowadzić do stwierdzenia, że w tym świetle niektóre zachowania seksualne mogłyby być usprawiedliwiane. Maurizio Faggioni podkreśla, że istnieją obiektywne kryteria dla oceny dojrzałej i w pełni ludzkiej praktyki seksualności, z uwzględnieniem konkretnych wrażliwości i norm zachowań (por. Faggioni 2017, s. 309).

Pierwsi chrześcijanie musieli skonfrontować wizję seksualności, wypływającą z biblijnego i Chrystusowego wykładu wiary, z rzeczywistością starożytnych, którzy w różnej mierze uznawali godziwość aktów seksualnych z małoletnimi. W starożytnej Grecji pederastia, czyli afektywny związek dorosłego z dojrzewającym młodzieńcem, którego celem było wprowadzenie go w świat dorosłych, czyli strukturę greckiej polis, nie byłaby tożsama z naszym 
rozumieniem pedofilii. $\mathrm{W}$ prawie ateńskim akty seksualne $\mathrm{z}$ dziećmi były natomiast surowo karane. W Imperium Rzymskim zakazywano chłopcom siadania $\mathrm{z}$ dorastającymi. Zachowały się świadectwa nadużyć seksualnych wobec dzieci, co również było obwarowane ciężkimi karami (por. Faggioni 2017, s. 309-310).

Idąc za stoickim postrzeganiem seksualności, chrześcijaństwo od początku bardzo rygorystycznie patrzyło na kwestię pedofilii, co znajduje odzwierciedlenie w wielu pismach ojców Kościoła, opierających się głównie na tekstach Mk 9,42 i Mt 18,6. Wystarczy przywołać tu List Barnaby z I wieku, Didachè z początku II stulecia, teksty św. Klemensa Aleksandryjskiego, gdzie pojawia się termin grecki paidóphthoros, czyli moralne i seksualne psucie dzieci. W 305 roku synod w Elwirze w kan. 81 zakazał udzielania Komunii św. tym, którzy gwałcili dzieci. Do konsekwencji grzechu zgorszenia maluczkich przez ludzi Kościoła nawiązywał w VI wieku św. Grzegorz Wielki w swojej Regule pasterskiej. Słowa te cytował w czasie przejmującego nabożeństwa 29 maja 2010 roku Charles J. Scicluna, ówczesny promotor sprawiedliwości w Kongregacji Nauki Wiary (por. Magister 2010).

W okresie średniowiecza libri poenitentiales zawierały różne normy, dotyczące popełniających grzechy seksualne z dziećmi, które to czyny określano pojęciami łac. stuprum, in terga. Jeszcze do XVI wieku młodych, nawet w wieku dojrzewania, postrzegano za osoby obojętne seksualnie, dlatego gesty erotyczne były uważane za niemające jakichkolwiek konsekwencji moralnych (Faggioni 2017, s. 311). Dopiero pedagogika kształtowana przez Towarzystwo Jezusowe i innych autorów tego czasu doprowadziła do odrzucenia wszelkich ataków seksualnych na dzieci i młodzież. Sformułowana wówczas zasada niedotykania (łac. regula tactus) pozostaje wyrazem podstawowego szacunku do osoby i jej nietykalności. Miała ona pomagać bronić nieletnich przed nadużyciami, regulować normy wszelkiego kontaktu z dziećmi i młodzieżą oraz rugować wszelkie ambiwalentne zachowania (por. Wirth 2013). Pewną kontynuacją tej myśli jezuickiej było umieszczenie przez św. Roberta Bellarmina, członka Towarzystwa Jezusowego, w dwóch dziełach katechetycznych, grzechów wołających o pomstę do nieba, wśród których wymieniany jest ,grzech cielesny przeciwko naturze" (wł. il peccato carnale contro natura) (Bellarmino 1839, s. 41-42; Marchesini 2013, s. 30-31). Maurizio Faggioni stwierdza, że kolejne wskazania pedagogiczne od XVIII wieku znalazły wyraz w postawie respektu dla dzieci, kontynuowanej w XIX stuleciu przez propagowanie konieczności rugowania wszelkich wspomnień na temat seksualności z czasów dzieciństwa i życia młodzieńczego, zgodnie z ówczesną tendencją dużej obawy przed sferą seksualną (por. Faggioni 2017, s. 311-312).

Zauważone w XIX wieku dzięki psychoanalitycznym poszukiwaniom Zygmunta Freuda różne sfery świadomości człowieka, łącznie z odkryciem 
przeżywania seksualności także w wieku dziecięcym, rzuciły nowe światło na perwersyjne zachowania seksualne dorosłych, próbując thumaczyć je przeżyciami psychicznymi z pierwszych lat życia. Z drugiej strony inne spojrzenia psychologiczne, uwrażliwienie społeczeństw na tego typu przestępstwa seksualne, odkrycie terapii i szacunku do dziecka doprowadziły do uformowania się nowej wrażliwości na godność nieletnich (por. Faggioni 2017, s. 312). Niestety, zjawisko turystyki seksualnej, rozprzestrzenianie się pornografii, zwłaszcza za pośrednictwem Internetu, rynek handlu ludźmi, także dziećmi, różnice kulturowe i różne formy ubóstwa są ciągle przyczynami szerzenia się nadużyć seksualnych wobec nieletnich w całym świecie (por. Franciszek 2019b).

\section{Kategoria prawna i moralna czynów pedofilskich}

Niejednorodna ocena czynów pedofilskich w różnych kulturach i szerokościach geograficznych i wszechobecny relatywizm moralny nie powinny prowadzić do fałszywego przekonania, że ich materia i ciężkość z biegiem wieków osłabły w świetle katolickiej teologii moralnej i prawa kanonicznego. Mówiąc o nieuporządkowanym pożądaniu seksualnym, autorzy Katechizmu Kościoła katolickiego nazwą je „rozwiązłością”, ponieważ są one poszukiwaniem przyjemności „w oderwaniu od nastawienia na prokreację i zjednoczenie" (KKK, nr 2351).

W pio-benedyktyńskim Kodeksie prawa kanonicznego z 1917 roku nadużycia seksualne wobec nieletnich dotyczyły krzywdzenia osób poniżej 16 roku życia i znajdowały się w kategorii łamania dobrych obyczajów (por. kan. 2356-2359). Przestępstwo popełniał ten, kto z osobami płci męskiej lub żeńskiej poniżej wskazanego wieku dopuszczał się czynu nierządnego, czyli ,jakiegokolwiek działania zmierzającego do zaspokojenia popędu płciowego"; ponadto nie było istotne, czy osoby krzywdzone mają zdolność rozpoznania takiego czynu, czy też nie (Bączkowicz 1958, s. 542). W przypadku duchownych sytuacja zależała do stopnia święceń. Duchowni niższych święceń, którzy popełnili nadużycia seksualne wobec osób do 16 roku życia, mieli być odpowiednio ukarani, nie wyłączając wydalenia ze stanu duchownego. Według ówczesnego kodeksu (por. kan. 2359 §1 i §2) duchowni wyższych święceń, w przypadku popełnienia takiego typu przestępstw, mieli być suspendowani, ogłoszeni za podlegających infamii, pozbawieni wszystkich urzędów, beneficjów, godności i zajęć, a w ciężkich wypadkach nawet deponowani z urzędów (por. Bączkiewicz 1958, s. 544-545). Znamienne jest, że dawny Pontificale Romanum zawierał nawet liturgiczne obrzędy deponowania duchownych w takich okolicznościach.

Nowy Kodeks św. Jana Pawła II z 1983 roku przenosi akcent omawianych nadużyć i przestępstw z dobrych obyczajów na celibat kapłański (por. Sko- 
nieczny 2017, s. 136-137). Pomijając szczegółowe rozwiązania prawne, należy podkreślić, że redukcja liczby przestępstw w tej dziedzinie oraz granica wieku 16 lat, zapisane w tym Kodeksie, zostały zmienione przez tego samego papieża. Na mocy motu proprio Sacramentorum sanctitatis tutela z 30 kwietnia 2001 roku św. Jan Paweł II zdecydował, że wykorzystywanie seksualne osoby nieletniej poniżej 18 roku życia, którego dopuszcza się duchowny, zostało włączone do nowej listy przestępstw kanonicznych, zastrzeżonych Kongregacji Nauki Wiary.

Normy Kongregacji Nauki Wiary, opublikowane w 2010 roku pod tytułem De gravioribus delictis, powróciły do określenia omawianych przestępstw jako przeciwnych obyczajności, w przypadku duchownych nie wykluczając jednocześnie sprzeniewierzenia się celibatowi kapłańskiemu (por. Kongregacja Nauki Wiary 2010; Arrieta 2010; Skonieczny 2017, s. 136-138). W ten sposób na gruncie prawa usankcjonowano szerokie ujęcie czynu zabronionego, którym jest obecnie każda czynność zewnętrzna przeciwko szóstemu przykazaniu Dekalogu, chroniącego ludzką seksualność. Taktyka „podejścia duszpasterskiego" w odniesieniu do grzesznych i przestępczych zachowań albo „modelu terapeutycznego" doprowadzały bardzo często do recydywy, okazując niewystarczającą siłę sakramentu pokuty, brak jego praktykowania albo złe przeżywanie go przez sprawców (por. Kongregacja Nauki Wiary 2010, Wprowadzenie historyczne).

Nie zawsze normy prawne były egzekwowane, nadużycia zaś tuszowano i przemilczano, zarówno wśród świeckich, jak i duchowieństwa. Benedykt XVI zauważa, że kościelne prawo karne funkcjonowało w Kościele katolickim do późnych lat pięćdziesiątych XX wieku, a potem przestano je zachowywać. „Panowało przekonanie - twierdzi papież Ratzinger - że Kościół nie może być już Kościołem prawa, ale Kościołem miłości; nie powinien więc karać. W ten sposób zlikwidowano świadomość, że kara może być także aktem miłości” (Benedykt XVI 2011, s. 38). Co więcej, w powszechnej świadomości wielu duchownych i świeckich zaczęto konfundować zachowania homoseksualne i pedofilskie, a szerzacca się od połowy XX wieku rewolucja seksualna jeszcze bardziej zaciemniała nie tylko jurydyczny, ale i moralnych charakter nadużyć seksualnych wobec nieletnich.

$\mathrm{Z}$ punktu widzenia moralnego warto zwrócić uwagę na wspomnianą kategorię czynów wołających o pomstę do nieba. Wśród tych najcięższych grzechów ostatni papieże umieszczają również nadużycia seksualne wobec nieletnich. Szczególne znaczenie ciała ludzkiego, „mowa ciała”, a także wartość wolności, która wyklucza wszelki rodzaj przymusu i przemocy, każą uznać czyny pedofilskie za poważne zło moralne. Tego typu zachowania nie tylko godzą w godność dziecka i poważnie łamią humanistyczny wymiar ludzkiej seksualności, ale także objawiają ogromną dysproporcję między kształtującą 
się dojrzałością małoletniego a brakiem dojrzałości fizycznej, psychicznej, emocjonalnej, duchowej i moralnej ze strony krzywdzącego (por. Faggioni 2017, s. 320).

Święty Jan Paweł II na gruncie etyki personalistycznej przypomniał i rozwinął znaną z tradycji kategorię czynów „,wewnętrznie złych” (łac. intrinsece malum), które są zawsze złe, ze względu na swój przedmiot, niezależnie od intencji osoby działającej i okoliczności (por. VS, nr 80; KKK, nr 1756). Jeśli Sobór Watykański II do takich czynów zaliczał wszystko, co szkodzi godności ludzkiej, jak np. prostytucję (GS 2002, nr 27), to z pewnością czyny pedofilskie i wszelkiego rodzaju nadużycia seksualne wobec dzieci mogą być określone z punktu widzenia moralnego jako wewnętrznie złe.

Benedykt XVI tego typu zachowania wśród duchownych opisywał jako „szczególnie ciężki grzech, gdy ktoś, kto ma pomagać ludziom w drodze do Boga, komu na tej drodze powierza się dziecko, zamiast prowadzić je do poznania Boga, molestuje je i od Boga odwodzi” (Benedykt XVI 2011, s. 37). Opublikowany przez papieża emeryta wiosną 2019 roku na łamach czasopisma „Klerusblatt” esej Kościót a skandal wykorzystywania seksualnego zawierał diagnozę przyczyn obecnych trudności moralnych w ocenie nadużyć seksualnych. Tekst ten nie ukazał się w całości na łamach mediów watykańskich, jedynie Sergio Centofanti (2019) opisał go zwięźle w „L'Osservatore Romano". Benedykt XVI stwierdza, że dominacja konsekwencjalizmu etycznego, porzucenie opcji prawa naturalnego na rzecz oparcia teologii moralnej wyłącznie na Biblii, kwestionowanie nieomylności Magisterium Kościoła, a także gwarantyzm prawa oskarżonych doprowadziły do poważnego zaburzenia kategorii moralnych, zarówno ze strony sprawców nadużyć, jak i ich przełożonych, także we wspólnocie Kościoła katolickiego (por. Benedykt XVI 2019, s. 309-312). Objawiło to ogromny kryzys teologii moralnej i sakramentu pokuty.

W odniesieniu do zjawiska różnych form wykorzystywania seksualnego dzieci Franciszek używa mocnych określeń. Nazywa je „zbrodniami”, „,przestępstwami sprzeniewierzenia”, „obrzydliwościami”, a także „nadużyciami”, zaś w stosunku do osób duchownych potępia je w dosadnych słowach: „Kościół od wielu lat poważnie angażuje się w wykorzenienie zła nadużyć, które woła o pomstę do Pana, do Boga, który nigdy nie zapomina o cierpieniu doświadczanym przez wielu małoletnich z powodu duchownych i osób konsekrowanych: nadużyciach władzy, sumienia i nadużyciach seksualnych" (por. Franciszek 2019a, 34; Zollner 2017). W takich działaniach dostrzega nadużycie władzy, a także pewnego rodzaju niewolnictwo, które jest ,przejawem złego ducha”, ponieważ „w obliczu tak wielkiego okrucieństwa, tak wielkiej bałwochwalczej ofiary z dzieci składanej bożkowi władzy, pieniędzy, dumy, pychy, nie wystarczają wyjaśnienia empiryczne" (Franciszek 2019b, s. 23-24). 


\section{Odpowiedzialność jako kategoria moralna w sakramencie pokuty}

Jeśli miłość Boga i bliźniego jest jednym z powodów wyznawania grzechów w sakramencie pokuty, rodzi to pytanie o postawę odpowiedzialność tych wszystkich, którzy są w jakikolwiek sposób związani z samym grzechem nadużyć, z jego wyznawaniem, rozgrzeszaniem, a także ze skutkami tego grzechu. $Z$ tym sakramentem związanych będzie zatem wiele dylematów, które targają sumienia zarówno sprawców, jak i ofiar nadużyć seksualnych.

Człowiek jako istota wolna jest odpowiedzialny za swoje czyny, jeśli są one dobrowolne (por. KKK, nr 1734). Ta odpowiedzialność jest także wezwaniem do postępowania $\mathrm{w}$ dobru i zwiększania panowania nad swoimi zachowaniami. Z drugiej strony może ona być zmniejszona, a nawet zniesiona „na skutek niewiedzy, nieuwagi, przymusu, strachu, przyzwyczajeń, nieopanowanych uczuć oraz innych czynników psychicznych lub społecznych" (KKK, nr 1735). Jak już stwierdzono, z całej historii Magisterium Kościoła katolickiego jasno wynika, że każdy czyn pedofilski jest ciężkim wykroczeniem moralnym, które nosi jednocześnie znamiona czynu wewnętrznie złego (por. Zadykowicz 2011, s. 220).

W przypadku grzechów nadużyć seksualnych bardzo istotne wydaje się jasne rozgraniczenie różnego stopnia odpowiedzialności za nie w różnych kategoriach osób w jakiś sposób związanych z sytuacjami nadużyć: od sprawców, przez ofiary, przełożonych, aż po całą wspólnotę Kościoła. Największą odpowiedzialność ponosi, co oczywiste, sprawca czynów pedofilskich, a jest ona tym wyższa, im miał on większą poczytalność swojego działania. Tadeusz Zadykowicz (2011, s. 221) twierdzi, że z moralnej odpowiedzialności „wyłączeni są sprawcy z neurologicznymi uszkodzeniami mózgu, pozbawieni kontroli nad własnym postępowaniem i świadomości znaczenia popełnionych czynów (upośledzenie umysłowe, uzależnienie)". Niewłaściwe i niesprawiedliwe z punktu widzenia moralnego byłoby obarczanie taką samą odpowiedzialnością za nadużycia seksualne zarówno sprawców, jak i na przykład ich przełożonych, stosując w ten sposób opisaną przez René Girarda kosmiczną odpowiedzialność, daleką od wizji Hansa Jonasa czy Georga Pichta (por. Girard 1987; Picht 1981). Odwołując się do chrześcijańskiej kategorii sądu ostatecznego, Picht twierdzi, że myślenie odpowiedzialne jest równoznaczne z myśleniem rozumnym, które powinno polegać na dostrzeganiu konsekwencji własnego działania i postępowania. Dlatego myślenie o przeszłości nie może być jedynie stwierdzeniem faktu czegoś, ale winno motywować do postawienia pytania o konsekwencje i odpowiedzialność (por. Ciążela 2007, s. 33-35).

Z takiej perspektywy opisuje problem papież Franciszek w Liście do Ludu Bożego z dnia 20 sierpnia 2018 roku: „Wymiar i wielkość wydarzeń wymaga 
przyjęcia odpowiedzialności w sposób globalny i wspólnotowy. [...] Jestem świadomy wysiłku i pracy dokonywanej w różnych częściach świata w celu zabezpieczenia i realizacji niezbędnych działań, które zapewniłyby bezpieczeństwo i chroniłyby integralność dzieci oraz bezbronnych dorosłych, a także upowszechniania «zerowej tolerancji» i pełnej odpowiedzialności wszystkich, którzy popełniają lub ukrywają te przestępstwa" (Franciszek 2018a, 692-693). Papież Bergoglio o kategorii odpowiedzialności w stosunku do biskupów, którzy kierują powierzonymi sobie Kościołami partykularnymi, wspomina także w liście apostolskim Vos estis lux mundi z 2019 roku, napominając ich, by dbali o właściwe zachowanie przejrzystości działań. Zmieniła się również odpowiedzialność prawna biskupów za ukrywanie przestępstw i nadużyć. Ponadto Franciszek wprowadził do prawa kategorię „,osoby bezradnej”, którą jest „każda osoba chora, z ułomnościami fizycznymi lub umysłowymi albo pozbawiona wolności osobistej, która faktycznie, nawet sporadycznie, ogranicza jej zdolność rozumienia lub chcenia, czy też w inny sposób przeciwstawienia się agresji” (Franciszek 2019c). Przestępstwa przeciwko szóstemu przykazaniu Dekalogu wobec takiej osoby są traktowane tak samo jak w stosunku do małoletnich do 18. roku życia.

W świetle dotychczasowych rozważań rodzi się zatem wiele dylematów i pytań, dotyczących sakramentu pokuty: Jaka jest odpowiedzialność kapłana spowiednika, odpowiedzialność sprawcy czynów, ofiar, nie zapominając o odpowiedzialności przełożonych, jak i całej wspólnoty Kościoła? Chodzi tu przede wszystkim o odpowiedzialność moralną, czyli powinności, jakie można by wskazać w wypadku wymienionych grup osób, włączonych w sprawowanie sakramentu pokuty. Ponadto należy zastanowić się nad tym, jakich, nierzadko trudnych wyborów, muszą te osoby dokonywać w swoim sumieniu, a także w czasie sprawowania sakramentu pokuty?

\section{a) Odpowiedzialność kapłana spowiednika}

Kapłan w konfesjonale ma być obrazem Chrystusa, miłosiernego i troskliwego pasterza owiec, którego zadaniem jest osądzanie winy, a przede wszystkim udzielanie rozgrzeszenia. Wypełniając obowiązek wiązania i rozwiązywania, powierzony przez Chrystusa apostołom (por. J 20,22-23), spowiednik odgrywa rolę sędziego, lekarza, nauczyciela i ojca. Powinien w swojej posłudze dbać o osobistą świętość, być wrażliwy na problemy psychologiczne, a także okazywać ludzką wyrozumiałość (por. Selejdak 2010, s. 73-79). Wszystkie te przymioty spowiednika są bardzo istotne w przypadku wyznawania w spowiedzi grzechów dotyczących szóstego przykazania, a zwłaszcza nadużyć seksualnych. Ma on towarzyszyć penitentowi w odkryciu zła popeł- 
nionych grzechów, ale też pokazać drogę doświadczenia większego od nich miłosierdzia Bożego.

$\mathrm{Z}$ jednej strony kapłan może mieć do czynienia z osobą, która popełniła czyny pedofilskie. Powinien okazywać wiele roztropności w osądzaniu czynów sprawcy. Poważnym nadużyciem wydaje się w tym kontekście praktykowanie amatorskiej psychologii albo próba prowadzenia terapii zamiast zaproponowanie sprawcy pedofilii podjęcia specjalistycznej terapii psychologicznej lub psychiatrycznej.

Pewną trudność w posłudze spowiednika może wywołać wyznaczenie właściwej pokuty sakramentalnej i zadośćuczynienia za popełnione przestępstwo zarówno dla sprawcy, jak i tego, kto ukrywał jego czyn, np. jego przełożonego. Choć z punktu widzenia prawa okazjonalny upadek w tym grzechu z małoletnim wypełnia już znamiona czynu zabronionego (por. Skonieczny 2017, s. 152-153), a w sensie moralnym jest grzechem ciężkim, to określenie moralnej winy i odpowiedzialności sprawcy będzie zależało od wzięcia pod uwagę także intencji i okoliczności grzechu.

Dalsza trudność dotyczy faktu samego rozgrzeszenia. Jeśli celem spowiedzi jest danie lub odmówienie absolucji za grzechy popełnione, objęte aktem żalu i postanowieniem poprawy, w sytuacji sprawcy grzechu nadużyć seksualnych wobec małoletniego rodzić się może wiele pytań: Co zrobić, gdy z jego strony nie ma żadnej formy żalu za grzechy? Czy brak postanowienia poprawy jest wystarczający do nieudzielenia rozgrzeszenia? Jaką funkcję w ocenie moralnej aktów pedofilskich pełni uwzględnienie okoliczności utrwalonej skłonności pedofilskiej lub efebofilskiej? Jak powinno wyglądać rozgrzeszenie w przypadku notorycznych grzeszników w tej materii? W jaki sposób postępować z penitentami-kapłanami, którzy dopuszczają się czynów pedofilskich, a nawet popadają w recydywę? Czy można uzależniać udzielenie rozgrzeszenie od decyzji takiego penitenta o podjęciu terapii lub poinformowania przez sprawcę właściwych służb? Jak pomóc sprawcy takich nadużyć w dostrzeżeniu własnej odpowiedzialności za ukrywanie i niezgłoszenie przestępstwa?

Odpowiedzi na te pytania dają niektóre z ostatnich dokumentów Kościoła powszechnego i Kościoła w Polsce. W ostatnich latach zaczęła toczyć się w świecie dyskusja o tajemnicy sakramentalnej i wprowadzonym w niektórych krajach obowiązku powiadamiania państwowych organów ścigania przez osoby, które nabyły wiedzę o przestępstwach, których ofiarami są dzieci. W Polsce 13 lipca 2017 roku weszła w życie w tej kwestii nowelizacja art. 240 Kodeksu karnego (por. Kroczek 2017; Majer 2017). Konferencja Episkopatu Polski dokonała w związku z tym w 2017 roku oraz w 2019 roku nowelizacji wytycznych z 2014 roku (por. Konferencja Episkopatu Polski 2019). Wskazano w nich wyraźnie, że treścią zawiadomienia „nie mogą być w żadnym wypadku wiadomości uzyskane z sakramentalnego forum wewnętrznego 
(tajemnica spowiedzi)" (Konferencja Episkopatu Polski 2019, 17). Ponadto w sposób analogiczny powinno się traktować wiedzę nabytą podczas kierownictwa duchowego. Zaznaczono również, że dotyczy to także spowiedników i ojców duchownych, przygotowujących kandydatów do kapłaństwa i życia zakonnego (por. Konferencja Episkopatu Polski 2019, Aneks nr 3, art. 2, p. 4). Warto nadmienić, że w niektórych krajach (np. w Belgii, we Włoszech) w ostatnich latach ustawodawcy próbują wymusić na duchownych zeznawanie posiadanej wiedzy o pedofilii, nabytej podczas sprawowania sakramentu pokuty (por. Boni 2019).

Rozwiązania Konferencji Episkopatu Polski zostały udzielone w duchu wyjaśnień, których udzieliła Penitencjaria Apostolska w Nocie z 2019 roku. Przypomniano w niej, że kapłan w Kościele katolickim zawsze sprawuje sakramenty in persona Christi capitis; staje się on świadomy grzechów penitenta „,non ut homo, sed ut Deus - nie jako człowiek, ale jako Bóg, do tego stopnia, że po prostu «nie wie», co mu powiedziano podczas spowiedzi dlatego, że nie słuchał jako człowiek, ale właśnie w imię Boga" (por. Penitencjaria Apostolska 2019, 10). Spowiednika zatem obowiązuje absolutna tajemnica (łac. sigillum sacramentale) co do jakichkolwiek grzechów, które zostały wyznane przez penitenta, nawet wówczas, gdy spowiednik nie udzieliłby absolucji (por. KKK, nr 1467; Penitencjaria Apostolska 2019, 10). W Nocie zostało ponadto sprecyzowane, że obrona świętości spowiedzi nie jest próbą ukrywania prawdy o jakichkolwiek przestępstwach czy wyznawanym przez grzeszników złu, ale jest antidotum na to zło. W świetle wskazań watykańskiego trybunału miłosierdzia nie można w stosunku do sprawcy nadużyć seksualnych wobec nieletnich, który wyznaje grzechy i za nie żałuje, stawiać pewnych warunków rozgrzeszenia: „Wobec grzechów, które mają charakter przestępstwa, nigdy nie wolno stawiać penitentowi, jako warunku rozgrzeszenia, obowiązku oddania się organowi sprawiedliwości publicznej, na mocy zasady z prawa naturalnego, włączonej w każdy porządek prawny, zgodnie z którą nemo tenetur se detegere" (Penitencjaria Apostolska 2019, 11). Wydaje się, że trzeba czytać te słowa, biorąc pod uwagę także okoliczności wyjawione przez sprawcę, powtarzalność czynów i zakres wyrządzonego zła. Niemniej jednak Penitencjaria przypomina, że skrucha, połączona $\mathrm{z}$ postanowieniem poprawy, jest warunkiem ważności sakramentu pokuty (por. Penitencjaria Apostolska 2019, 11).

Choć prawo polskie chroni wyłącznie sigillum sacramentale, ustanawiając zakaz przesłuchiwania (art. 178, p. 2 Kodeksu postępowania karnego i art. 82, p. 3 Kodeksu postępowania administracyjnego) lub prawo odmowy zeznań (art. $261 \S 2$ Kodeksu postępowania cywilnego) przez duchownego co do faktów objętych tajemnicą spowiedzi, to przywołując wskazania Penitencjarii Apostolskiej oraz opinię Piotra Majera, należy stwierdzić, że obowiązek powiadamiania nie dotyczy także wiedzy z kierownictwa duchowego, które 
należy traktować analogicznie do tajemnicy spowiedzi (por. Konferencja Episkopatu Polski 2019, art. 17; Majer 2017).

Kapłan sprawujący posługę w konfesjonale jest ważnym elementem budowania nowej świadomości i przełamywania „kultury milczenia” w kwestii nadużyć seksualnych. Właściwa postawa spowiednika, pełne współczucia, miłosierdzia i dobroci podejście do ofiar tych nadużyć, ale też roztropne i ojcowskie wysłuchanie sprawców, mogą być ważnym krokiem naprzód w nawróceniu poszczególnych osób, w stosownym ukształtowaniu ich wiary i relacji z Bogiem, a także w modelowaniu nierzadko niewłaściwie uformowanych sumień. Częściej w konfesjonale spowiednik będzie miał do czynienia $\mathrm{z}$ ofiarami i ich rodzinami, zatem właśnie do niego należy zadanie budzenia wrażliwości i nadziei oraz pierwsza pomoc duchowa i podstawowe wskazania psychologiczne w bolesnych przeżyciach. Jest to tym bardziej istotne, jeśli weźmie się pod uwagę fakt, że wejście w życie od 2017 roku sankcji karnych na płaszczyźnie prawa polskiego może powodować zwiększone poczucie winy u niektórych penitentów i wracanie do przeżyć z przeszłości w czasie wyznawania grzechów.

Wśród trudności, z jakimi może się spotkać spowiednik, jest kwestia wiarygodności wyznawanych grzechów i nadużyć seksualnych oraz oskarżeń kierowanych wobec różnych osób. Kapłan powinien cierpliwie pomagać penitentowi oceniać stawiane zarzuty, pamiętając jednocześnie o tym, że w czasie sprawowania sakramentu pokuty obowiązuje zasada domniemania prawdy wyznawanych grzechów (łac. paenitentibus credendum est) (por. Paluch 2016, s. 14-21). Nierzadkim, niestety, przypadkiem w dobie mediów cyfrowych jest niebezpieczeństwo nagrywania spowiedzi w celu skompromitowania spowiednika, zwłaszcza za pouczenie w dziedzinie nadużyć seksualnych, co miało miejsce np. w jednej z parafii diecezji płockiej w 2009 roku (por. Kurkiewicz 2009).

Wspomniane trudności objawiają konieczność nieustannej formacji stałej spowiedników, zarówno na płaszczyźnie duchowej, jak i intelektualnej.

\section{b) Odpowiedzialność ofiar}

Różnego rodzaju przeżycia, związane z dramatem wykorzystania seksualnego, bywają wypowiadane przez ofiary tych czynów w czasie spowiedzi. Niejednokrotnie same ofiary odczuwają ogromne poczucie winy, zupełnie nieadekwatne do przeżytej sytuacji. Niezastąpione jest więc mądre działanie spowiednika, który będzie potrafił ukierunkować uczucia, emocje i przeżycia skrzywdzonego penitenta. W tym najpełniej będzie się wyrażała postawa towarzyszenia Kościoła i leczenia ran pokrzywdzonych. Franciszek przypomina, że zadaniem Kościoła, a w nim spowiednika, jest „marnowanie czasu na 
słuchanie”. Papież stwierdza: „Słuchanie leczy zranionego i leczy także nas samych $\mathrm{z}$ egoizmu, $\mathrm{z}$ dystansowania się, $\mathrm{z}$ «to mnie nie dotyczy», z postawy kapłana i lewity z przypowieści o Miłosiernym Samarytaninie" (Franciszek 2019b, s. 25). To właśnie do spowiednika należy wyjaśnienie penitentowi, że jednym z elementów jego uzdrowienia osobistego oraz leczenia społecznych skutków grzechu pedofilii jest poszukiwanie sprawiedliwości wobec sprawców. Penitencjaria Apostolska w tym kontekście podkreśla: „Jeśli przychodzi penitent, który padł ofiarą zła innych, niech spowiednik pouczy go o jego prawach, w tym o konkretnych instrumentach prawnych, które posłużą do zgłoszenia i potępienia faktu na forum cywilnym i/lub kościelnym oraz przywróceniu sprawiedliwości" (Penitencjaria Apostolska 2019, 11). Stosowne jest jednocześnie uspokajanie ofiar, że nie ponoszą one ani odpowiedzialności karnej (por. art. 240 § 2a Kodeksu karnego), ani moralnej, jeśli z wiadomych sobie powodów i obaw nie przedstawią sprawy władzom cywilnym i kościelnym. Istotne jest uwrażliwienie ofiar na potrzebę precyzyjnego mówienia prawdy o czynach sprawców, by nie doprowadzić do bezpodstawnych pomówień, które mogą być obarczone winą moralną. Rozmowa ze spowiednikiem winna pomóc ofierze w rozstrzygnięciu wszelkich wątpliwości w tej kwestii.

W przypadku ofiary przestępstw nadużyć seksualnych, którą byłaby osoba przygotowująca się do przyjęcia sakramentu święceń, słuszne wydaje się zobligowanie kandydata przez spowiednika do podjęcia tego tematu podczas kierownictwa duchowego i zapoczątkowanie leczenia ran z przeszłości.

Dzięki właściwie przeżytemu procesowi leczenia duszy i psychiki ofiara nadużyć seksualnych może w przyszłości stać się pomocą dla innych osób, dlatego bardzo ważne jest właściwe przeżywanie przez nią sakramentu pokuty. Z punktu widzenia etycznego odpowiedzialność moralna ofiary wyrażałaby się zatem w odkryciu, w jaki sposób jej dramatyczne przeżycia mogą zostać w jej życiu uzdrowione, a ponadto, jeśli znalazłaby w sobie siłę ku temu, jakimi środkami mogłaby wesprzeć inne ofiary nadużyć seksualnych, które znalazły się w podobnym położeniu.

\section{c) Odpowiedzialność sprawcy czynów pedofilskich}

W jasnych słowach kwestię odpowiedzialności sprawców czynów nadużyć seksualnych wobec nieletnich zawarł w swoim apelu papież Franciszek, zwracając się do nich: „nawróćcie się i oddajcie się w ręce ludzkiej sprawiedliwości, i przygotujcie się na Bożą sprawiedliwość, pamiętając o słowach Chrystusa: «Kto by się stał powodem grzechu dla jednego z tych małych, którzy wierzą we Mnie, temu byłoby lepiej kamień młyński zawiesić u szyi i utopić 
go w głębi morza» (Mt 18,6)" (Franciszek 2019a, 35). Najbardziej istotnym problemem spowiedzi sprawcy pedofilii jest uznanie przez niego winy i podjęcie postanowienia poprawy, które są niezbędnymi elementami do otrzymania absolucji sakramentalnej, o czym już wyżej wspomniano przy okazji odpowiedzialności spowiednika.

Na czym polega zło grzechu pedofilii? Jakie dylematy powinno ono prowokować w sumieniu sprawcy? Po pierwsze, sprawca pedofilii przez swoje czyny zakłamuje sens cielesności i języka ciała (nazywanego także „mową ciała”). Poprzez swoje ciało człowiek może odkryć wezwanie i zaproszenie do bezinteresownego i pełnego miłości oddania drugiemu człowiekowi, mężczyzna kobiecie, a kobieta mężczyźnie. Nie może się to dokonywać przez łamanie norm moralnych prawa Bożego i prawa naturalnego, z użyciem przemocy, podporządkowania, przymusu moralnego lub fizycznego. Teologia ciała, rozwinięta zwłaszcza w nauczaniu św. Jana Pawła II, wskazuje ponadto na ważną rolę wstydu w kształtowaniu sfery seksualnej i obyczajowej, szczególnie dojrzewającego młodego człowieka (por. Marczewski 2015, s. 105-164). Akt seksualny pedofila i osoby nieletniej w wyraźny sposób zakłamuje takie personalistyczne traktowanie osoby oraz ciała, przez które ta osoba się wyraża, jest on bowiem pozbawiony wszelkiego szacunku dla dojrzałości fizycznej, psychicznej, uczuciowej i seksualnej, a może zasiać jedynie strach, lęk i przemoc. Przemoc seksualna jednoczy ciała, ale zaprzecza powołaniu, do jakiego zostało to ciało stworzone (Benanti i Zollner 2019, s. 11-12). Pedofil jest zatem odpowiedzialny za działanie sprzeczne z prawem naturalnym, za zgorszenie maluczkich i powodowanie ogromnej traumy psychicznej u swojej ofiary (lub ofiar), jak również odpowiada za stosowanie przemocy i zła wobec często bezbronnej, niewinnej osoby.

Po drugie, w ocenie moralnej czynów pedofilskich sprawcy, jak w innych patologiach natury psychicznej, trzeba wziąć pod uwagę wolność i świadomość wykonanego przez niego czynu oraz środowisko obyczajowe, w którym dopuścił się on nadużyć względem nieletnich. Sprawca czynów pedofilskich, który oczekuje rozgrzeszenia w sakramencie pokuty, winien zadać sobie pytanie nie tylko o dokonane fizycznie akty seksualne, ale też o to, w jaki sposób walczył z pokusami do tego typu grzechów, co uczynił, aby przeszkodzić kształtowaniu w swojej wyobraźni obrazów i wspomnień, które mogłyby go skłonić do podjęcia niegodziwych działań. Niektórzy autorzy wymieniają w tym względzie działania w świecie wirtualnym, grooming, sexting, pornografię i podobne czyny. Franciszek zauważył, że „świat cyfrowy i korzystanie z jego urządzeń często oddziałuje głębiej niż myślimy" (Franciszek 2019b, s. 25). Niemniej ważne w ocenie moralnej jest wzięcie pod uwagę, czy sam sprawca czynów pedofilskich nie był w przeszłości jako dziecko ofiarą podobnych działań ze strony dorosłych (por. Benanti i Zollner 2019, s. 12). 
Szczególnym przypadkiem sprawcy nadużyć seksualnych wobec nieletnich jest duchowny. Oceniając skalę zjawiska pedofilii w tej grupie społecznej, Jacek Prusak próbuje nakreślić profil sprawcy-duchownego, co może być pomocne we właściwym towarzyszeniu w sakramencie pokuty: „Na tle innych przestępców wykorzystujących nieletnich księża, którzy dopuścili się takich czynów są zazwyczaj starsi, lepiej wykształceni, z wyższym IQ, z mniejszą liczbą cech antyspołecznych, rzadziej też popełniali czyny kryminalne w przeszłości. Częściej wykorzystują nastoletnich chłopców oraz częściej mówią o orientacji homoseksualnej niż inni przestępcy seksualni w stosunku do nieletnich. Ogólnie występuje u nich mniej wskaźników psychopatologii, a także wykorzystują mniejszą liczbę ofiar" (por. Prusak 2015, s. 23). Każe to postawić pytanie o wpływ formacji kapłańskiej, osobistego kształtowania duchowości, życia sakramentalnego na trwałe nawrócenie duchownego sprawcy pedofilii. Są sprawcy, którzy widzą winę osobistą, ale też i tacy, którzy jej nie dostrzegają, a potrafią ją wyjaśnić, używając nawet argumentów religijnych. Rodzi się zatem pytanie o to, jak kapłan, który wielokrotnie popełnia czyny pedofilskie, spowiadał się wcześniej, jak wyglądały pouczenia spowiednika i co zrobił, aby zmienić swoje postępowanie? Fundamentalną kwestią wydaje się więc - przede wszystkim w przypadku kapłanów - właściwe dysponowanie własną seksualnością, dbałość o czystość seksualną i niestosowanie zgubnych psychologicznych mechanizmów obronnych w sytuacji odczuwania impulsów życiowych, poszukiwanie ekwilibrium między acedią i inercją, czyli lenistwem i bezwładem. Jest to wszystko możliwe dzięki dbałości o stałą formację kapłańską, której wagę w tej dziedzinie podkreśla nowa Ratio fundamentalis institutionis sacerdotalis z 8 grudnia 2016 roku (por. Zollner 2018, s. 71-74).

\section{d) Odpowiedzialność przełożonych}

Spowiedź sakramentalna może być przestrzenią wyznawania grzechów przez różnego rodzaju przełożonych, którzy czując odpowiedzialność za powierzone im zakłady pracy, wspólnoty lub grupy ludzi, mogą nabywać wiedzę o popełnionych przez członków tych społeczności nadużyciach seksualnych. Obok prawnego obowiązku powiadamiania władz państwowych o takich przestępstwach rodzi się pytanie o moralną odpowiedzialność przełożonych za zaistniałe sytuacje. Sakrament pokuty winien być okazją do wykonania przez nich rachunku sumienia z wprowadzonych działan prewencyjnych, kształtowania wrażliwości i szacunku wobec nieletnich, a także wprowadzania procedur prawnych i jasnych zasad reagowania w sytuacjach odkrycia potencjalnych nadużyć. Spowiedź daje także okazję do dostrzeżenia osobistej oceny danego faktu przez przełożonego w świetle porad i słów spowiednika, który może po- 
móc zweryfikować stopień odpowiedzialności, a także postawić zasadniczy dylemat, czy odbyty sakrament pokuty może zamknąć wszystko w kwestii odpowiedzialności za ukrywanie czynów pedofilskich, czy też należałoby podjąć inne kroki w celu naprawienia krzywd, na które się przyzwalało. Wszystkie te starania powinny pomóc odczytać penitentowi sprawującemu odpowiedzialne funkcje potrzebę osobistej troski o ziemską reparację i uświadomienie sobie wagi życia każdego człowieka, w którym dokonuje się zmaganie o wieczne zbawienie zarówno ofiar nadużyć, ich sprawców, jak i osób ich ukrywających.

Przywołując biblijną historię króla Dawida, papież Franciszek uwypukla znaczenie wrażliwości sumienia każdego człowieka, zwłaszcza przełożonego, i przestrzega: „Od iskier gnuśności i pożądliwości, od «osłabienia czujności» rozpoczyna się diabelski łańcuch grzechów ciężkich: cudzołóstwo, kłamstwo i morderstwo” (Franciszek 2019a, 34) i dodaje: „osoby, które nie czują, aby dopuszczały się poważnych uchybień przeciwko Prawu Bożemu, mogą postępować w swego rodzaju ogłuszeniu lub odrętwieniu. Ponieważ nie znajdują one w sobie nic poważnego, co mogłyby sobie wyrzucać, nie zauważają tej letniości, która stopniowo opanowuje ich życie duchowe, a ostatecznie marnują się i ulegają zepsuciu" (GE, nr 164).

Do powyższych uwag należy także dodać pytanie o troskę przełożonych o pomoc ofiarom nadużyć seksualnych, spowodowanych przez ich podwładnych, zapewnienie pokrzywdzonym dyskrecji, bezpieczeństwa i opieki, a także zorganizowanie pomocy psychologicznej, duchowej i nie mniej istotnego materialnego wsparcia. To także winno być przedmiotem refleksji w czasie rachunku sumienia przełożonego.

Kultura milczenia (wł. omertà) przez wiele lat sprawiała, że nadużycia seksualne i różne formy nadużyć władzy nie znajdowały właściwych rozwiązań także we wspólnocie Kościoła katolickiego. Symboliczny, a przez niektórych uważany za kontrowersyjny, był gest modlitwy Jana Pawła II i przepraszania za grzechy ludzi Kościoła, wykonany przed cudownym wizerunkiem Ukrzyżowanego z kościoła św. Marcelego w Rzymie w czasie obchodów Wielkiego Jubileuszu Chrześcijaństwa 12 marca 2000 roku. W ostatniej modlitwie tego nabożeństwa abp Paul Josef Cordes przepraszał za obojętność wobec godności tych, których papież Polak w swojej modlitwie nazwał „maluczkimi” (por. Weigel 2005, s. 1112-1113). Był to u progu trzeciego tysiąclecia pierwszy krok przełożonych Kościoła katolickiego do uznawania win i ich odpowiedzialności w sferze nadużyć seksualnych.

Okresem negatywnych przewartościowań moralnych w Kościele katolickim w dziedzinie odpowiedzialności przełożonych za nadużycia seksualne była połowa XX wieku, co wnikliwie opisuje Benedykt XVI we wspomnianej analizie z 2019 roku. Rewolucja obyczajowa lat sześćdziesiątych XX wieku dała wielu duchownym liczne argumenty do usprawiedliwiania grzesznych 
czynów osobistych i ich braci. Negatywne konsekwencje potęgowały, zdaniem papieża seniora, „kliki homoseksualne, które działały mniej lub bardziej otwarcie i znacząco zmieniły klimat w seminariach", a prowadzone procesy i ujawnianie kolejnych skandali nie zmieniały nastawienia do poważnych nadużyć w dziedzinie seksualnej wśród duchownych na różnych szczeblach hierarchii kościelnej w Europie i Stanach Zjednoczonych Ameryki Północnej (por. Benedykt XVI 2019, s. 309-312). Zapoczątkowana przez Jana Pawła II, pogłębiona w czasie pontyfikatu Benedykta XVI, konsekwentnie realizowana oraz egzekwowana przez Franciszka droga oczyszczenia oraz zasada ,zera tolerancji” dla nadużyć seksualnych wobec nieletnich, dają nadzieję na powolne zmienianie myślenia przełożonych, także kościelnych, i podejmowanie różnych pozasakramentalnych działań ekspiacyjnych za gorszące postawy i grzechy. Franciszek uzasadnia to w stanowczy sposób: „Święta bojaźń Boża nakazuje nam oskarżyć siebie - jako ludzi i jako instytucję - oraz zaradzić naszym niedociągnięciom. Oskarżenie samych siebie: to mądry początek, związany ze świętą bojaźnią Boga. Trzeba uczyć się oskarżania samych siebie, jako osoby, jako instytucje, jako społeczeństwa. Nie możemy bowiem wpaść w pułapkę oskarżania innych, będącego krokiem w kierunku alibi, które oddziela nas od rzeczywistości” (Franciszek 2019b, s. 25).

Pozytywnie należy ocenić stwierdzenia i drogę, nakreśloną przez Radę Stałą Konferencji Episkopatu Polski w słowie z 22 maja 2019 roku, po emisji filmu dokumentalnego Tylko nie mów nikomu (por. Rada Stała Konferencji Episkopatu Polski 2019). Biskupi polscy zwrócili uwagę właśnie na odpowiedzialność przełożonych za prewencję i ochronę nieletnich: „Przyznajemy, że jako pasterze Kościoła nie uczyniliśmy wszystkiego, aby zapobiec krzywdom". Pokreślono ponadto, by nie stosować w tej sprawie zasady odpowiedzialności zbiorowej, a win konkretnych sprawców grzechów pedofilskich nie przenosić na posługę wszystkich kapłanów. To ważny krok do dalszej refleksji nad kwestią odpowiedzialności przełożonych, co zostało doprecyzowane pod względem prawnokanonicznym przez papieża Franciszka w liście Vos estis lux mundi $\mathrm{w} 9$ maja 2019 roku (por. Franciszek 2019c).

\section{e) Odpowiedzialność wspólnoty Kościoła}

Choć grzech jest zawsze aktem pojedynczej osoby, wynika bowiem z wolnej decyzji człowieka, to św. Jan Paweł II zwrócił uwagę na jego społeczne skutki. Czynniki zewnętrzne i wewnętrzne mogą ograniczać wolność i odpowiedzialność za popełnione zło. Nie oznacza to jednak, twierdzi papież Polak, kwestionowania osobistej wolności pojedynczej osoby. Niektóre grzechy można, w sensie analogicznym, nazwać społecznymi, gdyż są nie tylko ob- 
razą Boga i jego miłości, ale też wyraźnie skierowane są przeciwko miłości bliźniego. Święty Jan Paweł II mówił o społecznych grzechach przeciwko życiu, dobru wspólnemu, prawom osoby ludzkiej (por. RP, nr 16). Niewątpliwie grzechy nadużyć seksualnych wobec nieletnich mają charakter społeczny, są one bowiem, jak słusznie przyznał także Franciszek, ,zjawiskiem rozpowszechnionym historycznie we wszystkich kulturach i społeczeństwach", wiele z nich nie jest zgłaszanych i monitorowanych, a większość z nich dokonuje się w środowisku rodzinnym (por. Franciszek 2019b, s. 22 i 27).

Uczciwe ujęcie kwestii pedofilii nakazuje uznać, że nie tylko duchowni katoliccy są sprawcami takich czynów, ale są one problemem społecznym, dotyczącym rzeczywistości życia publicznego wielu państw i narodów. Franciszek podkreśla, że „mamy do czynienia z problemem uniwersalnym, transwersalnym, który niestety występuje niemal wszędzie. Trzeba powiedzieć jasno: powszechność tej plagi, potwierdzająca jej groźny charakter w naszych społeczeństwach, nie umniejsza jej potworności w obrębie Kościoła" (Franciszek 2019b, s. 23). Dostrzeganie problemu, mówienie o nim, poszukiwanie dróg rozwiązania jest właściwą drogą do budzenia ludzkich sumień, kształtowania nowej wrażliwości i postrzegania grzechu, którego ohyda wcześniej nie przebijała się do świadomości licznych osób i wspólnot. To właściwa droga przygotowania do sakramentu pokuty, w którym pojedynczy człowiek może zyskać odpuszczenie grzechów.

Warto przypomnieć, że ostatnie lata przyniosły poważną zmianę w tej dziedzinie. Organizowane na różnych poziomach w Kościele Rzymskokatolickim nabożeństwa pokutne, dni postu, umartwienia i modlitwy za ofiary pedofilii stały się okazją do ogólnowspólnotowego rachunku sumienia z zaniedbań, grzechów i przewinień w dziedzinie nadużyć seksualnych i nadużyć władzy. Marszrutę historyczną procesu dochodzenia do nowej świadomości w tej dziedzinie przedstawiono $\mathrm{w}$ związku z watykańskim spotkaniem, zatytułowanym Ochrona nieletnich $w$ Kościele 21-24 lutego 2019 roku (por. Lombardi 2019; Timeline of the Church's 2019).

Pierwsze w Polsce nabożeństwo pokutne za grzechy wykorzystania seksualnego dzieci i młodzieży przez duchownych zostało zorganizowane w Krakowie 20 czerwca 2014 roku. Papież Franciszek 30 czerwca 2015 roku zwrócił się $\mathrm{z}$ apelem do krajowych konferencji biskupich o zorganizowanie w poszczególnych krajach dni modlitwy i pokuty za grzechy wykorzystywania seksualnego osób małoletnich. W Polsce pierwszy taki dzień został przewidziany na 3 marca 2017 roku, a od 2018 roku pierwszy piątek wielkiego postu został uznany przez Konferencję Episkopatu Polski za dzień modlitwy i pokuty za grzechy wykorzystania seksualnego małoletnich.

Wśród niemałej liczby wiernych podnoszona jest wątpliwość, czy cała wspólnota Kościoła powinna podejmować czyny pokutne za grzechy pedofi- 
lii nielicznych. Odpowiedź na to dubium daje papież Franciszek w Liście do Ludu Bożego: „Wezwanie św. Pawła, by cierpieć z cierpiącymi, jest najlepszym antidotum przeciwko jakiejkolwiek chęci wypowiadania nadal naszymi ustami słów Kaina: Czyż jestem stróżem brata mego? (Rdz 4,9)" (Franciszek 2018a, s. 693). Los brata, nawet tego, który jest winien grzechu i przestępstwa, nie może być obojętny całej wspólnocie wierzących.

W tym kontekście może się zrodzić jeszcze jedno pytanie, dotyczące odpowiedzialności wspólnoty Kościoła w wymiarze pokuty. Wypełnianie czynów miłosierdzia, „wyobraźnia miłosierdzia”, o którą prosił wielokrotnie św. Jan Paweł II, powinny kierować sumienia wierzących do postawienia kwestii, w jaki sposób cała wspólnota może wynagrodzić krzywdy, które zostały wyrządzone poszczególnym osobom. Nie chodzi tu bynajmniej o odpowiedzialność zbiorową, bo grzech zawsze jest dziełem pojedynczej osoby, niemniej jednak zaniedbaniem byłoby zupełne pomijanie w osobistym rachunku sumienia przez poszczególnego wyznawcę Chrystusa pytania, w jaki sposób, na miarę swoich możliwości, mógłby pomóc zmniejszyć konsekwencje zła, które dotknęło jednego z najmniejszych.

Choć wszystkie powyższe działania dotyczą forum externum i mogą one mieć pewien wpływ na kształtowanie postaw, przekazywanie treści i moderowanie dyskusji publicznej, to można żywić nadzieję, że przełożą się także na różne działania i formację sumień wielu osób w społeczeństwach, dotkniętych plagą nadużyć seksualnych.

\section{Wnioski}

Sprawowanie sakramentu pokuty i pojednania jest ważnym sposobem świadczenia Bożego miłosierdzia pokutującemu grzesznikowi oraz wobec całej wspólnoty Kościoła. Ostatnie lata pokazują, jak wiele zawiłości w tej dziedzinie związanych jest z problemem nadużyć seksualnych i nadużyć władzy. Kratki konfesjonału są intymnym miejscem spotkania ze sprawiedliwością i miłosierdziem Bożym, które jest niezmierne dla ofiar takich czynów, a także dla ich sprawców, gdy za nie żałują i postanawiają poprawę. Najpełniej wówczas realizuje się towarzyszenie człowiekowi i kształtowanie jego sumienia, nawet jeśli było błędnie uformowane. Postawa odpowiedzialności różnych osób, włączonych w sprawowanie sakramentu pokuty, pomaga zrozumieć, jak bardzo grzechy pedofilii i im podobne rujnują więzy międzyludzkie oraz wiarę w Boga.

Coraz większa wrażliwość społeczna na problem, ujawnianie i czynienie zadość złu czynów pedofilskich, a także ogromna praca wykonana dotychczas w tym względzie we wspólnocie Kościoła katolickiego na różnych szczeblach 
dają nadzieję na to, by nie zamykać całej sprawy jedynie w konfesjonale. Tragiczne historie osób molestowanych w dzieciństwie, które ujrzały światło dzienne, pokazały, że niewystarczająca była powtarzana przez lata, nie tylko w dziedzinie pedofilii, teza, której zwolennicy twierdzili, że Kościół ma swoje narzędzia oczyszczania, a najlepiej czynić to jedynie w sakramencie pokuty. Nieprzykładanie właściwej wagi do zadośćuczynienia paradoksalnie osłabiło zaufanie wielu wiernych do spowiedzi i doprowadziło do kryzysu pokuty i pojednania.

Pomocą w odkryciu na nowo wartości tego sakramentu może być refleksja nad problemem nadużyć seksualnych w świetle tradycyjnych pięciu warunków sakramentu pokuty. Nowe rozumienie cielesności, postęp nauk szczegółowych, jak np. psychologii, rodzą potrzebę napisania właściwych rachunków sumienia dla dzieci, młodzieży i dorosłych, dla kapłanów, dla przełożonych, z uwzględnieniem pytań o szóste i dziewiąte przykazanie oraz nadużycia seksualne. Poważnej katechezy domaga się kwestia żalu za grzechy i postanowienia poprawy, które w przypadku sprawców takich nadużyć mogą rodzić różnego rodzaju wątpliwości. Niemniej istotne byłoby przypomnienie tradycyjnej nauki o współudziale w grzechu cudzym, szczególnie w sytuacji przełożonych lub mających wiedzę na temat nadużyć seksualnych. Ponadto zadośćuczynienie, istotny warunek sakramentu pokuty, może być szansą na doprecyzowanie kolejnych zagadnień: pokuty dla przełożonych, ukrywających świadomie nadużycia seksualne, popełnione przez ich podwładnych; sposobu znajdowania środków na pomoc ofiarom; przywracania dobrego imienia fałszywie oskarżonym o czyny pedofilskie, a także rozstrzygnięcie na gruncie prawa kanonicznego potrzeby wprowadzenia kary ekskomuniki za nadużycia seksualne wobec nieletnich.

Rany i skażenie ludzi Kościoła konsekwencjami nadużyć seksualnych mogą być leczone przez sakrament pokuty i pojednania. Nawet jeśli wydawać się może, że obecna sytuacja jest dopiero początkiem sporów i różnego rodzaju oskarżeń, nierzadko związanych z odkrywaniem cieni przeszłości, nie powinno to powodować utraty nadziei na zwycięstwo prawdy, bo Kościół składa się z dobrych i złych ryb. Benedykt XVI z przekonaniem stwierdza: „Jeśli z czujnym sercem rozglądamy się wokół i słuchamy, możemy dzisiaj wszędzie, szczególnie pośród zwykłych ludzi, ale także w wysokich rangach Kościoła, odnaleźć świadków, którzy swoim życiem i cierpieniem stają w obronie Boga. Lenistwo serca sprawia, że nie chcemy ich dostrzec" (Benedykt XVI 2019, s. 317). 


\section{DILEMMAS OF THE SACRAMENT OF PENANCE AND RECONCILIATION IN THE CONTEXT OF SEXUAL ABUSES AGAINST MINORS IN THE LIGHT OF THE TEACHING OF POPE FRANCIS}

\section{Summary}

Sexual abuse against minors painfully hurts the entire community of the Catholic Church. The sacrament of penance and reconciliation is one of the fundamental realities in which healing the wounds of victims is carried out, as well as appealing to the consciences of perpetrators. The purpose of the article is to show the various dilemmas of the sacrament of penance and reconciliation in the context of sexual abuses of minors, especially in the light of the teaching of Pope Francis. The difficult moral issues discussed concern both confession of victims of pedophilia and perpetrators of these sins. The problem of the moral responsibility of the superiors of abusers is also raised, as well as the question of the responsibility of the entire community of the Catholic Church for shaping proper moral thinking about the sins of abuse.

Keywords: sacrament of penance and reconciliation; sexual abuses; minors; pope Francis; responsibility; superiors; secret of confession; pedophilia

Słowa kluczowe: sakrament pokuty i pojednania; nadużycia seksualne; nieletni; papież Franciszek; odpowiedzialność; przełożeni; tajemnica spowiedzi; pedofilia

\section{WYKAZ SKRÓTÓW}

GE - Franciszek, Adhortacja apostolska «Gaudete et exsultate» o powolaniu do świętości w świecie wspótczesnym.

GS - Sobór Watykański II, Konstytucja duszpasterska o Kościele w świecie współczesnym Gaudium et spes.

KKK - Katechizm Kościoła katolickiego.

RP - Jan Paweł II, Adhortacja apostolska Reconciliatio et poenitentia.

VS - Jan Paweł II, Encyklika Veritatis splendor.

\section{BIBLIOGRAFIA}

Arrieta J.I. (2010), L'influsso del Cardinal Ratzinger nella revisione del sistema penale canonico, „La Civiltà Cattolica”, 3851, s. 430-440.

Arrieta J.I. (2019), Riservatezza e dovere di denuncia, „L'Osservatore Romano”, 288, 18 dicembre, s. 4-5.

Bellarmino R. (1839), Dottrina cristiana breve composta per ordine di Papa Clemente VIII al R.P. Roberto Bellarmino della Compagnia di Gesù poi cardinale di Santa Chiesa, Roma. 
Benanti P., Zollner H. (2019), Abuso sessuale, w: Teologia morale, red. P. Benanti i in., Cinisello Balsamo, s. 5-13.

Benedykt XVI (2011), Świattość świata. Papież, Kościót i znaki czasu. Benedykt XVI w rozmowie $z$ Peterem Seewaldem, tłum. P. Napiwodzki, Kraków.

Benedykt XVI (2019), Kościól a skandal wykorzystywania seksualnego (polskie thumaczenie tekstu), „Miesięcznik Pasterski Płocki” 104(4), s. 305-317.

Beretta R. (2019), Oltre l'abuso: Lo scandalo della pedofilia farà cambiare la Chiesa?, Milano.

Boni G. (2019), Sigillo sacramentale e segreto ministeriale. La tutela tra diritto canonico e diritto secolare, „Stato, Chiese e pluralismo confessionale. Rivista telematica” 34, s. 1-93. DOI: 10.13130/1971-8543/12850.

Centofanti S. (2019), Tornare a Dio per superare la crisi degli abusi, „L'Osservatore Romano” 85, 12 aprile, s. 7.

Ciążela H. (2007), Etyka odpowiedzialności (spojrzenie z perspektywy odpowiedzialności globalnej), „Kultura i Edukacja” 3, s. 23-36.

Di Noto F. (2002), La pedofilia. I mille volti di un olocausto silenzioso, Milano.

Faggioni M. (2017), Sessualità, matrimonio, famiglia. Nuova edizione, Bologna.

Franciszek (2015), Chirographus «Minorum tutela actuosa», „Acta Apostolicae Sedis” 107(6), s. $562-563$.

Franciszek (2018a), Niech Duch Święty da nam taskę nawrócenia i zadośćuczynienia. List do Ludu Bożego, „L'Osservatore Romano”, 39(8-9), s. 7-9.

Franciszek (2018b), Adhortacja apostolska «Gaudete et exsultate» o powołaniu do świętości w świecie współczesnym, Kraków.

Franciszek (2019a), Kościół nigdy nie będzie próbowat ukryć ani bagatelizować żadnego przypadku nadużyć. Przemówienie do członków Kurii Rzymskiej (Watykan, 21 grudnia 2018 r.), „L’Osservatore Romano" 40(1), s. 32-37.

Franciszek (2019b), Stanowczo apeluję o wszechstronna walkę przeciwko wykorzystywaniu nieletnich. Przemówienie na zakończenie obrad poświęconych ochronie nieletnich (Watykan, 24 lutego 2019 r.). „L'Osservatore Romano”, 40(3), s. 22-29.

Franciszek (2019c), Lettera apostolica in forma Motu proprio «Vos estis lux mundi», „L'Osservatore Romano", 106, s. 10.

Girard R. (1987), Kozioł ofiarny, tłum. M. Goszczyńska, Łódź.

Jan Paweł II (1984), Adhortacja apostolska Reconciliatio et poenitentia, Città del Vaticano.

Jan Paweł II (1993), Encyklika Veritatis splendor, Città del Vaticano.

Katechizm Kościoła katolickiego (2002), Poznań.

Kobyliński A. (2003), Dramat pedofilii, „Przegląd Powszechny” 7-8, s. 229-231.

Kobyliński A. (2017), Pedofilia w Belgii: rewolucja seksualna, sekularyzacja i nowa moralność, „Studia Bobolanum” 28(1), s. 219-236.

Kobyliński A. (2018), Pedofilia we Włoszech: skala problemu, aspekty etyczne i ochrona nieletnich, „Studia Ecologiae et Bioethicae” 16(1), s. 37-58. DOI: 10.21697/seb.2018.1.04.

Konferencja Episkopatu Polski (2019), Uchwała nr 14/384/2019 Konferencji Episkopatu Polski $z$ dn. 8 października $2019 \mathrm{r}$. w sprawie nowelizacji «Wytycznych dotyczacych wstępnego dochodzenia kanonicznego w przypadku oskarżeń duchownych o czyny przeciwko szóstemu przykazaniu Dekalogu z osobq niepetnoletnia poniżej osiemnastego roku życia», https://episkopat.pl/ wp-content/uploads/2019/10/NowelilzacjaWytycznychDotyczacychWstepnegoDochodzeniaK anonicznegoWPrzypadkuOskarzenDuchownychOCzynyPrzeciwkoSzostemuPrzykazaniuDeka loguZOsobaNiepełnoletniaPonizejOsiemnastegoRokuZycia.pdf_[dostęp: 31.12.2019].

Kongregacja Nauki Wiary (2010), Normae de gravioribus delictis, „Acta Apostolicae Sedis” 102(7), s. $419-430$.

Kroczek P. (2017), Kilka uwag do znowelizowanych «Wytycznych» Konferencji Episkopatu Polski $w$ kontekście zasad techniki legislacyjnej oraz znowelizowanego art. 240 § 1 kodeksu karnego, „Annales Canonici” 13, s. 91-107. DOI: 10.15633/acan.2221. 
Kurkiewicz R. (2009), Reporter „,Faktów i Mitów” ekskomunikowany, https://www.rp.pl/artykul/ 367311-Reporter--Faktow-i-Mitow--ekskomunikowany-.html_[dostęp: 23.09.2009].

Lombardi F. (2019), Protezione dei minori: una missione globale per la Chiesa in uscita, „La Civiltà Cattolica" 4048, s. 329-342.

Magister S., Documenti. Quando il grande inquisitore predica in San Pietro, http://magister.blogautore.espresso.repubblica.it/2010/05/31/documenti-quando-il-grande-inquisitore-predica-in-sanpietro/?refresh_ce [dostęp: 01.04.2020].

Majer P. (2017), Państwo i Kościól zaostrzaja kurs wobec pedofilii. Możliwe dylematy sumienia, http://wiez.com.pl/2017/07/14/panstwo-i-kosciol-zaostrzaja-kurs-wobec-pedofilii-mozliwedylematy-sumienia/ [dostęp: 14.07.2017].

Marchesini R. (2013), Omosessualità e Magistero della Chiesa. Comprensione e speranza, Milano.

Marcinek P., Kapała A. (2012) Pedofilia w opiniowaniu sądowo-seksuologicznym, „Seksuologia Polska" 10(2), s. 76-84.

Marczewski R. (2015), Teologia ciała Jana Pawła II w praktyce amerykańskiego Kościoła, Kraków.

Paluch, K. (2016), Obowiazki i zadania spowiednika, „Sympozjum” 20(1), s. 9-26.

Penitencjaria Apostolska (2019), Nota o ważności forum wewnętrznego i nienaruszalności pieczęci sakramentalnej, thum. R. Leżohupski. Niepokalanów.

Picht G. (1981), Odwaga utopii, thum. K. Maurin, K. Michalski, K. Wolnicki, Warszawa.

Prusak J. (2009), Pedofilia, w: Encyklopedia bioetyki. Personalizm chrześcijański, red. A. Muszala, Radom, s. 469-477.

Prusak J. (2015), Duchowny-pedofil, czyli kto?, „Dziecko Krzywdzone. Teoria, badania, praktyka” 14(1), s. 14-29.

Rada Stała Konferencji Episkopatu Polski (2019), Wrażliwość i odpowiedzialność, https://ekai.pl/dokumenty/wrazliwosc-i-odpowiedzialnosc-slowo-biskupow-do-wiernych/_dostęp: 31.12.2019].

Secretaria Status (2015), Statuta Pontificiae Commissionis pro pupillis tuendis, „Acta Apostolicae Sedis" 107(6), s. 564-567.

Selejdak R. (2010), Kapłan penitentem i szafarzem sakramentu pokuty i pojednania, „Collectanea Theologica" 80(1), s. 57-80.

Skonieczny P. (2017), Przestępstwo cięższe przeciwko szóstemu przykazaniu Dekalogu z matoletnim - uwagi «de lege lata» $i$ «de lege ferenda», „Prawo Kanoniczne” 60(1), s. 135-175. DOI: 10.21697/pk.2017.60.1.08.

Sobór Watykański II (2002) Konstytucja duszpasterska o Kościele w świecie współczesnym Gaudium et spes, w: Sobór Watykański II, Konstytucje, dekrety, deklaracje, Poznań.

Timeline of the Church's Response on the local and universal levels, https://www.pbc2019.org/protection-of-minors/timeline_[dostęp: 31.12.2019].

Weigel G. (2005), Świadek nadziei. Biografia papieża Jana Pawła II, thum. M. Romanek i in., Kraków.

Wirth M. (2013), Regula tactus. Zur Aktualität einer kirchlichen Norm als Prävention und Plädoyer gegen sexualisierte Gewalt, „Wege zum Menschen” 65(2), s. 185-195. DOI: 10.13109/ weme.2013.65.2.185.

Zadykowicz T. (2011), Pedofilia. Aspekt moralny, w: Encyklopedia katolicka, red. F. Gryglewicz i in., t. 15, Lublin, kol. 220-221.

Zollner H. (2017), La tutela dell'infanzia nella Chiesa Cattolica, „La Civiltà Cattolica” 4001, s. 448-457.

Zollner H. (2018), Mój Boże, czemuś mnie opuścil? Duchowość a postępowanie w przypadkach wykorzystania seksualnego, „Życie Duchowe” 93, s. 67-83.

WoJCiech KućKo - ks. dr, Uniwersytet Kardynała Stefana Wyszyńskiego w Warszawie; zainteresowania badawcze: bioetyka, teologia moralna, pontyfikat Franciszka, hagiografia, e-mail: w.kucko@uksw.edu.pl. 